\title{
The Efficacy of Ginger for Pregnancy-Induced Nausea and Vomiting: A Systematic Review
}

\author{
Lamia AlHajri ${ }^{1}{ }^{1,}$, Moaza AlFalasi ${ }^{1}$, Munira Abdelrahim ${ }^{1}$ and Rawdha AlKaabi ${ }^{1}$ \\ ${ }^{1}$ Higher Colleges of Technology, Health Sciences Department - Pharmacy Division \\ ${ }^{2}$ Lancaster University, Department of Health Research
}

\begin{abstract}
Nausea and Vomiting (N/V) are unpalatable manifestations seen commonly during pregnancy, which impinge upon the overall well-being, the productivity and might result in hospitalization. There is growing evidence concerning the efficacy of ginger in alleviating Nausea and Vomiting in Pregnancy (NVP). Therefore, we sought to conduct a systematic review to explore the effectiveness of ginger for NVP. A comprehensive search was conducted in Google Scholar, PubMed, and Science Direct which resulted in identifying five studies. These studies showed that ginger can improve NVP in a statistically significant manner $(P<0.05)$. Assessing the safety profile of this agent was difficult due to the short duration of intervention, and inconsistency in the dose and dosage form of ginger used. This study helped to glean evidence about the efficacy of ginger in NVP. It also emphasized the need for conducting more studies with a better quality and that are using standardized dose and dosage forms to be able to conduct a meta-analysis.
\end{abstract}

Keywords: Ginger, Zingiber Officinale, NVP

\section{Background}

The development of Nausea and Vomiting in Pregnancy (NVP) is rife, affecting approximately $80 \%$ of pregnant females, where only $1 \%$ of these might progress to develop a severe form of NVP known as hyperemesis gravidarum ${ }^{1-3}$. NVP is commonly seen between the $5^{\text {th }}$ and the $18^{\text {th }}$ weeks of gestation, and affect the overall well-being of patients ${ }^{4}$. Importantly, the severity of the NVP varies among pregnants, and consequently, the management will vary as well. Although there are plenty of etiologies and pathophysiological theories underpinning NVP, it is still considered to be an area of controversy ${ }^{5}$. The importance of addressing NVP lies behind the possibility of developing dehydration, affecting the pregnancy, affecting the quality of life, productivity, and might lead to depression ${ }^{6}$. Treatment modalities incorporate identifying trigger factors and avoiding them, utilizing pharmacological and complementary agents and supportive therapy ${ }^{7-9}$.

Ginger (Zingiber officinale), which is a common ingredient in Asian meals, started gaining momentum as a treatment modality for $\mathrm{NVP}^{10}$. Noncompliance to medications and treatment plans is not uncommon among pregnant women which might be gauged by concerns related to fetus health ${ }^{11}$. However, herbal or complementary medicine tends to be more accepted as they are perceived to be a safer option although they might be not ${ }^{12}$. Hence, this systematic review aims at investigating the efficacy of ginger in relieving NVP. Although investigating the safety of this ingredient is imperative, the majority of studies included in this systematic review were conducted for a very short period (e.g. four days), and used different doses and dosage forms, therefore rendered this objective unachievable.

\footnotetext{
*Author for correspondence

Email: lamia.alhajri@hct.ac.ae
} 


\section{Methods}

\subsection{Search Strategy}

A systematic review of the literature was performed based on the Preferred Reporting Items for Systematic Reviews (PRISMA) guidelines ${ }^{13}$. Three electronic databases including Google Scholar, PubMed, and Science Direct, were explored using the following terms: 'safety and efficacy of ginger in pregnancy' and 'ginger in pregnancy'.

\subsection{Study Selection}

We reviewed papers of studies that met the following inclusion criteria and were available as a full text or purchased by the library of the Higher Colleges of Technology:

- Study design: randomized controlled trial.

- Study aim: evaluate the efficacy of ginger in NVP.

- Study population: pregnant women.

- Intervention: ginger in different doses.

- Comparator: traditional pharmaceutical products (vitamin $\mathrm{B}_{6}$, doxylamine), placebo, complementary medicine (wristband and acupuncture) or control.

- Publication language and year: English, and between the year 2007 and 2017.

- Jadad score: above or equal to 2 .

\subsection{Quality Assessment}

Jadad scale was utilized to assess the qualities of the randomized controlled trials included in this systematic review ${ }^{14,15}$. A score of $\leq 2$ indicates a low-quality design, while a score of $\geq 3$ indicates a high-quality design ${ }^{14,15}$.

\subsection{Review Procedure}

Three researchers were involved in the process of data extraction, and a fourth researcher afterward reviewed the extracted data.

\subsection{Data Extraction and Synthesis}

Data was extracted from studies using a standardized document, where information such as author/s, year of publication, objectives, methodology and methods, interventions and comparator/s, study duration, and main findings were easily amalgamated. Moreover, the results of the studies were synthesized narratively with all results presented in a tabulation format.

\subsection{Outcome Measures}

- Symptom scores on the subjective feeling of nausea was measured by standardized scales or methods [e.g. Visual Analogue Scale (VAS)].

- Vomiting episodes were measured through a daily recording.

- The general response to the treatment was measured by standardized scales or methods (e.g. the 5-point Likert-type scale and the Rhodes Index Likert-type scale).

\section{Results}

\subsection{Identification of Studies}

The searching process went through series of phases as displayed in Figure 1. In the first phase, specific terms were used as mentioned earlier to retrieve relevant studies. This resulted in retrieving 4410 studies from Google Scholar, 147 studies from Pubmed and 647 studies from Science Direct. In phase two, the aim was to screen titles for having the relevant key terms, use the inclusion criteria to filter out irrelevant studies either by going through abstracts or full texts, and by calculating the Jadad score (Figure 1). The outcome of this phase was identifying five studies to be incorporated in this systematic review (Figure 1).

All the studies included were exploring the efficacy of ginger in $\mathrm{NVP}^{16-20}$. The efficacy of this agent was tested using different scores as mentioned earlier including VAS, or Rhodes Index ${ }^{16-20}$. Different doses were also used in these studies, where the ginger doses ranged between $450 \mathrm{mg}$ per day to $1950 \mathrm{mg}$ per day ${ }^{16-20}$. Besides, the Jadad score of the studies included was either 2 or $5^{16-}$ ${ }^{20}$. Key data and findings of the randomized controlled trials are summarized in Table $1^{16-20}$.

\subsection{Summary of Trials}

Chittumma et al. (2007), conducted a study to compare the efficacy of ginger $1950 \mathrm{mg} /$ day and vitamin $\mathrm{B}_{6} 75$ $\mathrm{mg} /$ day for $\mathrm{NVP}^{16}$. Both medications were given for 
four days, and Rhodes index was utilized to assess the effectiveness of both interventions ${ }^{16}$. The Rhodes index of nausea and vomiting reduced among both groups "ginger and vitamin $\mathrm{B}_{6}$ ", and this decline was found to be statistically significant compared to baseline $(\mathrm{P}<0.05)^{16}$. The reduction in Rhodes index (mean \pm $\mathrm{SD})$ was $3.3 \pm 1.5$ in the ginger group, in comparison to $2.6 \pm 1.3$ in the vitamin $\mathrm{B}_{6}$ groups ${ }^{16}$, therefore, providing a clear indication that ginger was superior to vitamin $\mathrm{B}_{6}$ in a statistically significant manner $(\mathrm{P}<0.05)^{16}$. Yet, one patient in the ginger group and four patients in the vitamin $\mathrm{B}_{6}$ used other agents alongside the intervention and comparator agents which might have afflicted the results $^{16}$.

Ensiyed et al. (2007), conducted a study where 70 participants were randomly assigned to receive either ginger $1000 \mathrm{mg} /$ day or Vitamin $B_{6} 40 \mathrm{mg} /$ day for a period of four days ${ }^{17}$. The severity of nausea was assessed using VAS and Likert scales, while the vomiting was assessed by counting daily vomiting episodes ${ }^{17}$. Changes in nausea VAS score from baseline were $3.3 \pm 2.5$ and $1.3 \pm 2.2$ in the ginger and vitamin $\mathrm{B}_{6}$ groups, respectively $(\mathrm{P}<0.05)^{17}$. On the other hand, the changes in the vomiting episodes from baseline in both groups was found to be statistically not significant $(\mathrm{P}>0.05)^{17}$. When the ginger group and vitamin $\mathrm{B}_{6}$ were compared, it has been found that the ginger group was superior in terms of showing an improvement (82.8\%) in comparison to the vitamin $\mathrm{B}_{6}$ group $(67.6 \%)(\mathrm{P}>0.05)^{17}$. Yet, these findings were not statistically significant (Table 1 ).

Biswas et al. (2011), studied 63 participants for three weeks to evaluate the effectiveness of ginger $450 \mathrm{mg} /$ day in alleviating NVP ${ }^{18}$. Participants were randomly assigned to receive either $450 \mathrm{mg} /$ day of ginger or a combination of doxylamine and vitamin $\mathrm{B}_{6} 20 \mathrm{mg} / 30 \mathrm{mg}$ per day for a period of three weeks ${ }^{18}$ (Table 1). To assess improvement, VAS was utilized as well as counting the number of nausea spells and vomiting episodes ${ }^{18}$. Both groups showed a comparable and significant reduction in nausea and vomiting ${ }^{18}$. The median nausea VAS score dropped from 34.0 at baseline to 0 , while the median vomiting VAS score dropped from 14.50 to 0 by the end of the intervention in the ginger group $(\mathrm{P}<0.05)^{18}$. Furthermore, the median nausea VAS score dropped from 30.0 at baseline to 0 , while the median vomiting
VAS score dropped from 22.00 to 0 by the end of the intervention in the doxylamine/vitamin $\mathrm{B}_{6}$ group $(\mathrm{P}<0.05)^{18}$. Besides, the average number of nausea spells and vomiting episodes per day in both groups declined in a statistically significant manner $(\mathrm{P}<0.05)^{18}$.In fact, the median nausea spells went from 3 to 0.43 and the median vomiting episodes went from 1 to 0.14 by the end of the intervention $(\mathrm{P}<0.05)$ among the ginger users ${ }^{18}$. Additionally, the median nausea spells went from 4 to 0.60 , and the median vomiting episodes went from 2 to 0 in the other group $(\mathrm{P}<0.05)^{18}$. Despite the fact that, there was no head to head comparison between both groups, this study managed to shed light on the efficacy of ginger ${ }^{18}$.

Saberi et al. (2014), conducted a study on 151 participants who were randomly assigned to one of three groups which are the ginger, acupuncture, or control groups ${ }^{19}$. This study was designed to compare the difference in nausea, vomiting and retching before and after the intervention using Rhodes index ${ }^{19}$. Overall, there was a significant improvement in nausea, vomiting and retching Rhodes index after the interventionin all groups $(\mathrm{P}<0.05)^{19}$. However, the ginger group showed a higher improvement in the vomiting Rhodes scale compared to the acupuncture and control groups, as the mean Rhodes index in the ginger group dropped by approximately $42 \%$ compared to about $13 \%$ reduction in the other two groups ${ }^{19}$. Furthermore, the reduction in the nausea Rhodes index was found to be the highest in the ginger group (47\%), followed by the acupuncture (22\%) and the control groups $(2 \%)^{19}$. Besides, retchingRhodes index was reduced the most in the ginger group (46\%) followed by the acupuncture groups (35\%) (Table 1) ${ }^{19}$. Nevertheless, the control group showed an increase in the retching Rhodes index by $7 \%$ after the intervention ${ }^{19}$. However, a determination of the significance of these comparisons was not plausible, as the level of significance was not tested. unfortunately, the significance of these comparisons was not tested statistically ${ }^{19}$. Saberi et al. (2014), in a different study, drew a comparison between the ginger (750 mg/day), placebo and control groups regarding their efficacy for $\mathrm{NVP}^{20}$. The highest reduction in the Rhodes Index for all three parameters was seen among ginger users compared to the other groups, in a statistically significant manner $(\mathrm{P}<0.05)^{20}$. 


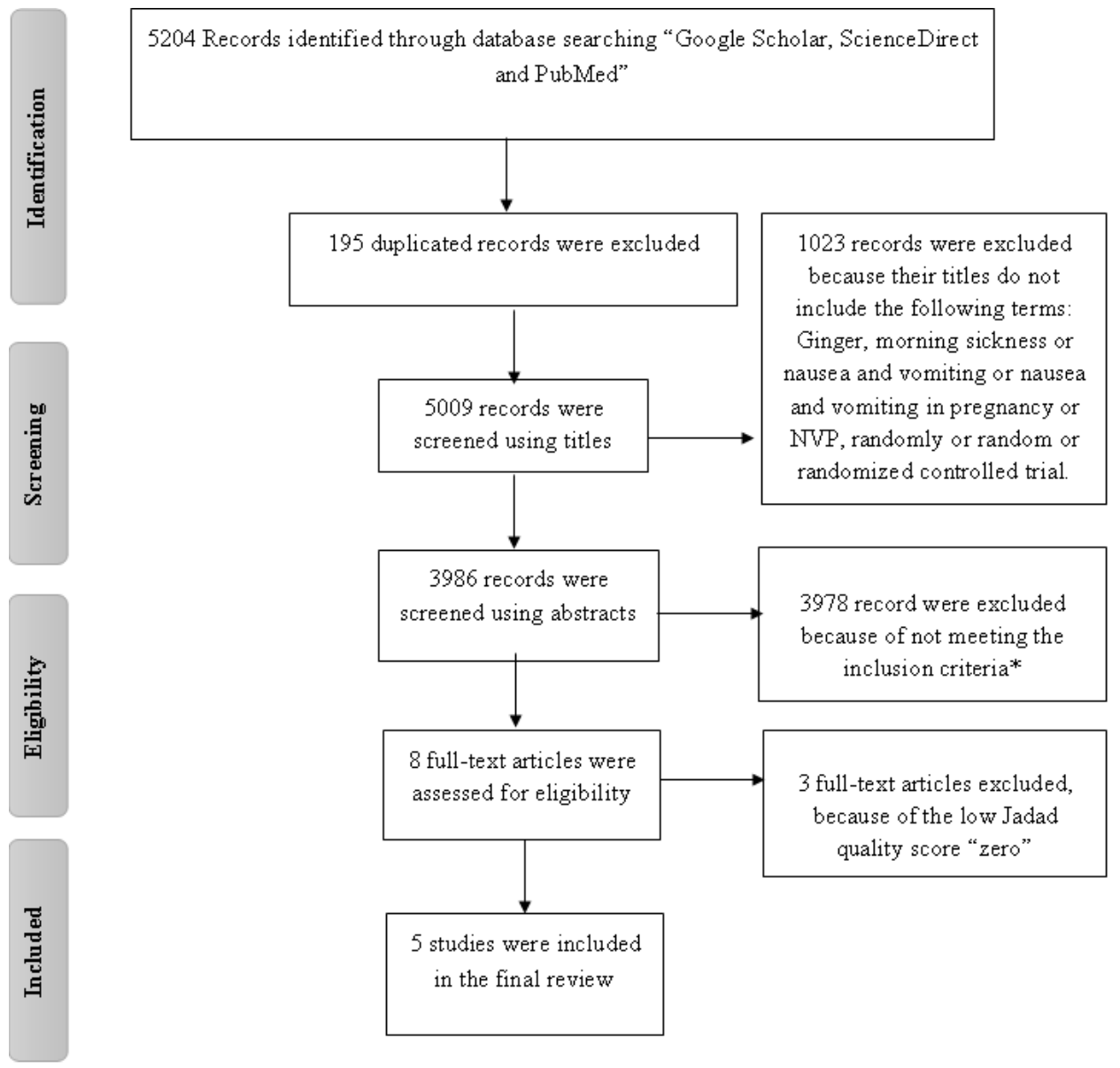

Fig. 1. PRISMA flow chart $^{13}$.

* A study that cannot be assessed sufficiently using abstract and is available as a full text, was assessed using the full text.

\section{Discussion}

The majority of the studies included in this systematic review brought to light that ginger powder a dose of 450 $\mathrm{mg}$ to $1950 \mathrm{mg}$ per day is effective in alleviating nausea and vomiting seen during pregnancy in a statistically significant manner ${ }^{16-20}$. In fact, some studies found that participants whom received ginger had a superior control over symptoms compared to the comparator groups (vitamin $\mathrm{B}_{6}$, placebo, control) ${ }^{16,17,19,20}$. These findings go in synchrony with some studies that demonstrated the efficacy of ginger in alleviating NVP, using a dose of 1 gram which is considered to be the most commonly used and tested dose $\mathrm{e}^{10,21-23}$.

Several mechanisms have been proposed with regards to the antiemetic effect produced by ginger including the carminative effect which breaks up the intestinal gas $^{24}$. This mechanism was supported by the results of a randomized, double-blind trial which demonstrated the ability of the ginger to accelerate gastric emptying and stimulated antral contractions ${ }^{24}$. Some asserted that the antiemetic effect results from the inhibition of serotonin receptors in the gastrointestinal system and the central nervous system 'vomiting center', as well as the inhibition of vasopressin which causes a reduction in tachygastric activity $^{25-29}$.

There are various active ingredients found in the ginger including gingerol, shogaol, and galanolactone, which produce antiemetic effects using difference mechanisms ${ }^{30-32}$. The ginger used for NVP should be obtained from Zingiber officinale, and not from other types of ginger with a different Latin name such as the ones that come from African or Thailand, due to the differences in the balance of chemical constituents ${ }^{30}$. Furthermore, the balance between these components varies between fresh, semi-dried and dried forms, therefore expecting to havevariations in responses produced by these forms ${ }^{30}$. 
Table 1: Results gleaned from RCTs

\begin{tabular}{|c|c|c|c|c|c|c|}
\hline Author & $\begin{array}{l}\text { Jadad } \\
\text { scale }\end{array}$ & $\begin{array}{l}\text { Patient population } \\
\text { and interventions } \\
\text { (Ginger \& } \\
\text { comparator/s) }\end{array}$ & Design & $\begin{array}{l}\text { Duration of } \\
\text { intervention }\end{array}$ & Outcome measures & $\begin{array}{l}\text { Results of the efficacy } \\
\text { parameters }\end{array}$ \\
\hline $\begin{array}{l}\text { Chittumma } \\
(2007)^{16}\end{array}$ & 5 & $\begin{array}{l}\text { Total number } \\
\text { of participants } \\
\text { completed the study } \\
(\mathrm{N}=123) \text { : } \\
\text { Ginger } 1950 \mathrm{mg} / \text { day } \\
(\mathrm{N}=61) \\
\text { Vitamin } \mathrm{B}_{6} 75 \mathrm{mg} / \\
\text { day }(\mathrm{N}=62)\end{array}$ & $\begin{array}{l}\text { Randomized } \\
\text { double } \\
\text { blinded } \\
\text { control study }\end{array}$ & 4 days & $\begin{array}{l}\text { Rhodes index }{ }^{1} \text { used } \\
\text { to assess nausea and } \\
\text { vomiting. The score } \\
\text { was taken at baseline } \\
\text { and then every day } \\
\text { till the end of the } \\
\text { intervention. }\end{array}$ & $\begin{array}{l}\text { Ginger group: } \\
\text { The difference in nausea } \\
\text { and vomiting scores } \\
\text { improved from baseline } \\
\text { in a statistically significant } \\
\text { manner }(\mathrm{P}<0.05) . \\
\text { Vitamin } \mathbf{B}_{\mathbf{6}} \text { group: } \\
\text { The difference in nausea } \\
\text { and vomiting scores } \\
\text { improved from baseline } \\
\text { in a statistically significant } \\
\text { manner }(P<0.05) . \\
\text { Ginger group vs. Vitamin } \\
\mathbf{B}_{6} \text { group: } \\
\text { The ginger group } \\
\text { demonstrated more } \\
\text { reduction in the Rhodes } \\
\text { Index compared to the } \\
\text { vitamin } B_{6} \text { group in a } \\
\text { statistically significant } \\
\text { manner }(P<0.05)\end{array}$ \\
\hline $\begin{array}{l}\text { Ensiyed et al. } \\
(2007)^{17}\end{array}$ & 5 & $\begin{array}{l}\text { Total number } \\
\text { of participants } \\
\text { completed the study } \\
(\mathrm{N}=70) \text { : } \\
\text { Ginger } 1000 \mathrm{mg} / \text { day } \\
(\mathrm{N}=35) \\
\text { Vitamin } \mathrm{B}_{6} 40 \mathrm{mg} / \\
\text { day }(\mathrm{N}=35)\end{array}$ & $\begin{array}{l}\text { Double- } \\
\text { blinded } \\
\text { randomized } \\
\text { controlled trial }\end{array}$ & 4 days & $\begin{array}{l}\text { VAS }{ }^{2} \text { and Likert scales } \\
\text { were used to assess } \\
\text { the severity of nausea. } \\
\text { While vomiting was } \\
\text { assessed by counting } \\
\text { the number vomiting } \\
\text { episodes per day. } \\
\text { The VAS }{ }^{2} \text { was taken } \\
\text { at baseline and then } \\
\text { every day for four } \\
\text { days, while the Likert } \\
\text { scale was taken at } \\
\text { baseline and then } \\
\text { one week after the } \\
\text { initiation of treatment } \\
\text { to evaluate the } \\
\text { treatment response. } \\
\text { The count for } \\
\text { vomiting episodes } \\
\text { was taken at baseline } \\
\text { and then every day for } \\
\text { four days. }\end{array}$ & 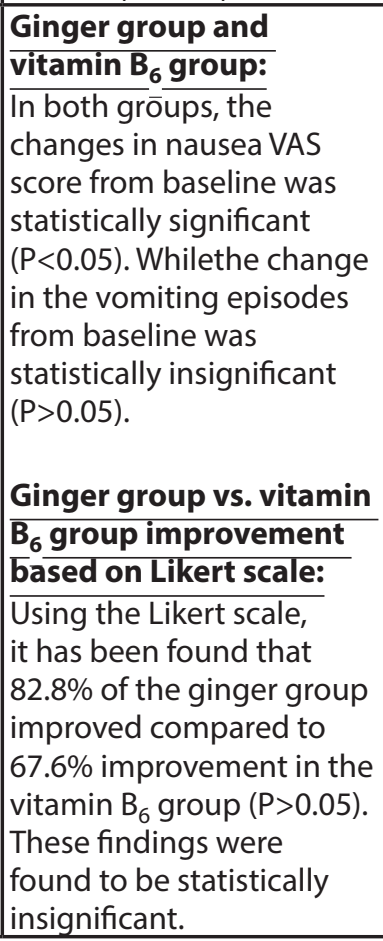 \\
\hline
\end{tabular}




\begin{tabular}{|c|c|c|c|c|c|c|}
\hline $\begin{array}{l}\text { Biswas et al. } \\
(2011)^{18}\end{array}$ & 2 & $\begin{array}{l}\text { Total number } \\
\text { of participants } \\
\text { completed the study } \\
(\mathrm{N}=63) \text { : } \\
\text { Ginger } 450 \mathrm{mg} / \text { day } \\
(\mathrm{N}=34) \\
\text { The combination of } \\
\text { doxylamine } 20 \mathrm{mg} \text { to } \\
30 \text { mg and Vitamin } \\
\mathrm{B}_{6} 20 \text { to } 30 \mathrm{mg} / \text { day } \\
(\mathrm{N}=29)\end{array}$ & $\begin{array}{l}\text { Single-blind } \\
\text { randomized } \\
\text { controlled trial }\end{array}$ & $\begin{array}{l}\text { Threeweeks, } \\
\text { but } \\
\text { participants } \\
\text { were } \\
\text { followed } \\
\text { up till the } \\
\text { delivery. }\end{array}$ & $\begin{array}{l}\text { The severity of nausea } \\
\text { and vomiting was } \\
\text { assessedVAS }{ }^{2} \text {,the } \\
\text { number of nausea } \\
\text { spells and vomiting } \\
\text { episodes. Two VAS } \\
\text { scores were taken } \\
\text { on each visit, one to } \\
\text { ask about the same } \\
\text { day, and the other } \\
\text { one to ask about the } \\
\text { previous week. The } \\
\text { average numbers of } \\
\text { nausea spells and } \\
\text { vomiting episodes } \\
\text { were recorded on } \\
\text { a daily basis and } \\
\text { reported on each visit. }\end{array}$ & $\begin{array}{l}\text { Ginger group and } \\
\text { doxylamine/ vitamin } \text { B }_{6} \\
\text { Group: } \\
\text { In both groups, the VAS } \\
\text { scores of nausea and } \\
\text { vomiting declined from } \\
\text { baseline in a statistically } \\
\text { significant manner } \\
(P<0.05) \text {. Also, the } \\
\text { mean of nausea spells } \\
\text { and vomiting episodes } \\
\text { reduced significantly } \\
(P<0.05) .\end{array}$ \\
\hline $\begin{array}{l}\text { Saberi et al. } \\
(2013)^{19}\end{array}$ & 2 & $\begin{array}{l}\text { Total number } \\
\text { of participants } \\
\text { completed the study } \\
(\mathrm{N}=143) \text { : } \\
\text { Ginger } 750 \mathrm{mg} / \text { day } \\
(\mathrm{N}=50) \\
\text { Acupressure } \\
\text { Wristband }(\mathrm{N}=48) \\
\text { Control }(\mathrm{N}=45)\end{array}$ & $\begin{array}{l}\text { Randomized } \\
\text { controlled } \\
\text { trial. }\end{array}$ & $\begin{array}{l}\text { Three days } \\
\text { without } \\
\text { intervention, } \\
\text { followed by } \\
\text { four days of } \\
\text { intervention. }\end{array}$ & $\begin{array}{l}\text { Rhodes score }{ }^{1} \text { for } \\
\text { nausea and vomiting } \\
\text { twice a day for seven } \\
\text { days. }\end{array}$ & $\begin{array}{l}\text { Ginger group: } \\
\text { The Rhodes index (mean) } \\
\text { for nausea, vomiting, } \\
\text { and retching reduced } \\
\text { significantly after the } \\
\text { introducing ginger } \\
\text { (P<0.05). } \\
\text { Acupressure Group: } \\
\text { The Rhodes index (mean) } \\
\text { for nausea, vomiting, } \\
\text { and retching reduced } \\
\text { significantly after the } \\
\text { introducing acupuncture } \\
\text { (P<0.05). } \\
\text { Control Group: } \\
\text { Rhodes index (mean) } \\
\text { for vomiting reduced } \\
\text { significantly after three } \\
\text { days of the start of the } \\
\text { study (P<0.05). However, } \\
\text { the Rhodes Index for } \\
\text { nausea and retching } \\
\text { did not show any } \\
\text { improvement (P }>0.05) .\end{array}$ \\
\hline $\begin{array}{l}\text { Saberi et al. } \\
(2014)^{20}\end{array}$ & 2 & $\begin{array}{l}\text { Total number } \\
\text { of participants } \\
\text { completed the } \\
\text { study with adequate } \\
\text { information for } \\
\text { assessment }(\mathrm{N}=106) \text { : } \\
\text { Ginger } 750 \mathrm{mg} \text { / day } \\
(\mathrm{N}=37) \\
\text { Placebo }(\mathrm{N}=36) \\
\text { Control }(\mathrm{N}=33)\end{array}$ & $\begin{array}{l}\text { Randomized } \\
\text { controlled trial }\end{array}$ & $\begin{array}{l}\text { Three days } \\
\text { without } \\
\text { intervention, } \\
\text { followed by } \\
\text { four days of } \\
\text { intervention. }\end{array}$ & $\begin{array}{l}\text { Rhodes score }{ }^{1} \text { for } \\
\text { nausea and vomiting } \\
\text { twice a day for seven } \\
\text { days }\end{array}$ & $\begin{array}{l}\text { Ginger Group vs. placebo } \\
\text { group vs. control group: } \\
\text { Reduction in nausea, } \\
\text { vomiting and retching } \\
\text { Rhodes indexes was the } \\
\text { highest in the ginger } \\
\text { group compared to } \\
\text { placebo and control } \\
\text { groups, and this } \\
\text { difference was found to } \\
\text { be statistically significant } \\
\text { (P<0.05). }\end{array}$ \\
\hline
\end{tabular}

${ }^{1}$ Rhodes score: 3 is the lowest score and a score of 15 indicating severe nausea and vomiting ${ }^{16-20}$.

${ }^{2}$ Visual Analogue Scale: $0=$ absence of nausea, $10=$ the most severe condition of nausea ${ }^{16-20}$.

$\mathrm{RCT}=$ Randomized controlled trial; VAS= visual analogue scale; $\mathrm{N}=$ sample size; $\mathrm{P}=\mathrm{p}$ value; $\mathrm{mg}=$ milligram . 
Differentiation between nausea and vomiting is of paramount importance to be able to derive accurate conclusions ${ }^{30}$. From a medical perspective, vomiting received more attention when measuring outcomes due to the concerns with regards to progressing tohyperemesis gravidarum ${ }^{30}$.On the other hand, nausea is considered to be more distressing, therefore paying attention to this component is imperative ${ }^{30}$. The vast majority of studies included in this systematic review looked into nausea as well as vomiting in a separated manner. Yet, the participants' understanding and their ability to differentiate between both concepts was not assessed or confirmed, which might impinge upon the accuracy of findings.

Using a natural product does not ensure safety which is a common misconception seen among lay public. Indeed, it has been found that Ginger might interact with anticoagulants and anti-platelets as ginger itself has an anticoagulant effect ${ }^{29,32-36}$. Furthermore, it is known to cause gastrointestinal irritation and is contraindicated in patients with or have a history of gallstones as it stimulates secreting bile ${ }^{37}$. Moreover, ginger is known to cause hypotension, and the possibility of cardiac arrhythmias, hence, cardiac patients should be warned ${ }^{30}$.

The correct dosage should be prescribed, although there is currently no consensus agreement on the maximum dose ${ }^{30}$. In Europe and North America, the maximum dose does not go beyond 2 gram per day, while in China, it may go up to 9 grams per day (although it is rarely used in pregnancy $)^{30}$. Hence, more research entailing ginger pharmacodynamics (effective and toxic doses) should be conducted to be able to have a unified guideline.

\section{Limitations}

Having a rudimentary understanding with regards to the limitation of this design is imperative. Publication bias will always be a concern in systematic review as it might lead to false positive overall conclusions. In fact, one of the major limitations of this systematic review is having limited access to certain studies that were not purchased by the academic institution. Furthermore, some studies might have still been in the publication process and not yet available on the web to encompass their findings in this review. With regards to the studies included in this systematic review, the inconsistencies in the comparators, the dose and the dosage form used, the outcome measures (tools) and the duration of the intervention made it difficult to perform a metaanalysis $^{16-20}$.

\section{Conclusion}

In conclusion, the findings of this systematic review decipher the efficacy of ginger in alleviating NVP. In fact, this review found that ginger is as effective if not superior to the comparators. Besides, it is considered to be an attractive alternative as it is readily available in every house, yet ensuring a proper dosing is crucial. Although it is anatural product, it is still associated with some adverse effects and interacts with other medications. More consistent studies need to be conducted to enable performing a meta-analysis, identify safe and effective dose ranges, appropriate duration of treatment, and consequences of overdosing.

\section{Authors Contributions}

All authors contributed to the study design. All authors were involved in the literature review and data extraction process. Besides, all participated in the writing and revision of the manuscript.

\section{Declaration of Conflicting Inter- ests}

The authors have no conflict of interest to declare.

\section{Funding}

The author(s) received no financial support for the research, authorship, and/or publication of this article.

\section{References}

1. Mazzotta P, Stewart D, Atanackovic G, et al. Psychosocial morbidity among women with nausea and vomiting of pregnancy: prevalence and association with antiemetic therapy. J Psychosom Obstet Gynaecol. 2000; 21:129-36. https://doi.org/10.3109/01674820009075620 PMid:11076334 
2. Chou F-H, Lin L-L, Cooney AT, et al. Psychosocial factors related to nausea, vomiting, and fatigue in early pregnancy. J Nurs Scholarsh Off Publ Sigma Theta Tau Int Honor Soc Nurs Sigma Theta Tau. 2003; 35:119-25. https://doi. org/10.1111/j.1547-5069.2003.00119.x

3. Swallow BL, Lindow SW, Masson EA, et al. Psychological health in early pregnancy: relationship with nausea and vomiting. J Obstet Gynaecol J Inst Obstet Gynaecol. 2004; 24:28-32.https://doi.org/10.1080/01443610310001620251 PMid:14675977

4. Madjunkova S, Maltepe C, Koren G, et al. The leading concerns of American women with Nausea and Vomiting of Pregnancy calling motherisk NVP helpline. Obstet Gynecol Int. 2013; 2013: e752980.

5. Ebrahimi N, Maltepe C, Einarson A. Optimal management of nausea and vomiting of pregnancy. Int $\mathrm{J}$ Womens Health. 2010; 2:241-8. https://doi.org/10.2147/IJWH. S6794 PMid:21151729 PMCid:PMC2990891

6. Einarson A, Maltepe C, Boskovic R, et al. Treatment of nausea and vomiting in pregnancy. Can Fam Physician. 2007; 53:2109-111. PMid:18077743 PMCid:PMC2231543

7. Arsenault M-Y, Lane CA, Mac Kinnon CJ, et al. The management of nausea and vomiting of pregnancy. J Obstet Gynaecol Can JOGC. 2002; 24: 817-31. https:// doi.org/10.1016/S1701-2163(16)30475-3

8. Ding $M$, Leach $M$, Bradley $H$. The effectiveness and safety of ginger for pregnancy-induced nausea and vomiting: a systematic review. Women Birth J Aust Coll Midwives. 2013; 26:e26-30. https://doi.org/10.1016/j. wombi.2012.08.001 PMid:22951628

9. Viljoen E, Visser J, Koen N, et al. A systematic review and meta-analysis of the effect and safety of ginger in the treatment of pregnancy-associated nausea and vomiting. Nutr J. 2014; 13:20. https://doi.org/10.1186/1475-289113-20 PMid:24642205 PMCid:PMC3995184

10. Borrelli F, Capasso R, Aviello G, et al. Effectiveness and safety of ginger in the treatment of pregnancy-induced nausea and vomiting. Obstet Gynecol. 2005; 105:849-56. https://doi.org/10.1097/01.AOG.0000154890.47642.23 PMid:15802416

11. Matsui D, Matsui D. Adherence with Drug Therapy in Pregnancy. Obstet Gynecol Int. 2011; 2012: e796590.

12. John LJ, Shantakumari N. Herbal medicines use during pregnancy: A review from the Middle East. Oman Med J. 2015; 30:229-36. https://doi.org/10.5001/omj.2015.48 PMid:26366255 PMCid:PMC4561638

13. Moher D, Liberati A, Tetzlaff J, et al. Preferred reporting items for systematic reviews and meta-analyses: The
PRISMA statement. Ann Intern Med. 2009; 151:264-9. https://doi.org/10.7326/0003-4819-151-4-20090818000135 PMid:19622511

14. Jadad AR, Moore RA, Carroll D, et al. Assessing the quality of reports of randomized clinical trials: Is blinding necessary? Control Clin Trials. 1996; 17:1-12. https://doi. org/10.1016/0197-2456(95)00134-4

15. Oxford Quality Scoring System. Available from: http:// www.pmidcalc.org/?sid=8721797\&newtest $=$ Y\#

16. Chittumma P, Kaewkiattikun K, Wiriyasiriwach B. Comparison of the effectiveness of ginger and vitamin B6 for treatment of nausea and vomiting in early pregnancy: A randomized double-blind controlled trial. J Med Assoc Thail Chotmaihet Thangphaet. 2007; 90:15-20.

17. Ensiyeh J, Sakineh M-AC. Comparing ginger and vitamin B6 for the treatment of nausea and vomiting in pregnancy: A randomised controlled trial. Midwifery. 2009; 25:649-53. https://doi.org/10.1016/j.midw.2007.10.013 PMid:18272271

18. Biswas S, Dey R, Kamliya G, et al. A single-masked, randomized, controlled trial of ginger extract in the treatment of nausea and vomiting of pregnancy. JIMSA $2011 ; 24: 167-9$.

19. Saberi F, Sadat Z, Abedzadeh-Kalahroudi M, et al. Acupressure and ginger to relieve nausea and vomiting in pregnancy: A randomized study. Iran Red Crescent Med J. 2013; 15:854-61. https://doi.org/10.5812/ircmj.12984 PMid:24616799 PMCid:PMC3929824

20. Saberi F, Sadat Z, Abedzadeh-Kalahroudi M, et al. Effect of ginger on relieving nausea and vomiting in pregnancy: A randomized, placebo-controlled trial. Nurs Midwifery Stud. Available from: http://www.ncbi.nlm.nih.gov/pmc/ articles/PMC4228518/

21. Ernst E, Pittler MH. Efficacy of ginger for nausea and vomiting: a systematic review of randomized clinical trials. Br J Anaesth. 2000; 84:367-71. https://doi.org/10.1093/ oxfordjournals.bja.a013442 PMid:10793599

22. Chaiyakunapruk N, Kitikannakorn N, Nathisuwan S, et al. The efficacy of ginger for the prevention of postoperative nausea and vomiting: A meta-analysis. Am J Obstet Gynecol. 2006; 194:95-9. https://doi.org/10.1016/j. ajog.2005.06.046 PMid:16389016

23. Bone ME, Wilkinson DJ, Young JR, et al. Ginger root- A new antiemetic. The effect of ginger root on postoperative nausea and vomiting after major gynaecological surgery. Anaesthesia. 1990; 45:669-71. https://doi. org/10.1111/j.1365-2044.1990.tb14395.x PMid:2205121 
24. Wu K-L, Rayner CK, Chuah S-K, et al. Effects of ginger on gastric emptying and motility in healthy humans. Eur J Gastroenterol Hepatol. 2008; 20:436-40. https://doi. org/10.1097/MEG.0b013e3282f4b224 PMid:18403946

25. Abdel-Aziz H, Nahrstedt A, Petereit F, et al. 5-HT3 receptor blocking activity of arylalkanes isolated from the rhizome of Zingiber officinale. Planta Med. 2005; 71:609-16. https://doi.org/10.1055/s-2005-871265 PMid:16041645

26. Abdel-Aziz H, Windeck $T$, Ploch $M$, et al. Mode of action of gingerols and shogaols on 5-HT3 receptors: Binding studies, cation uptake by the receptor channel and contraction of isolated guinea-pig ileum. Eur J Pharmacol. 2006; 530:136-43. https://doi.org/10.1016/j. ejphar.2005.10.049 PMid:16364290

27. Chrubasik S, Pittler MH, Roufogalis BD. Zingiberis rhizoma: A comprehensive review on the ginger effect and efficacy profiles. Phytomedicine Int J Phytother Phytopharm. 2005; 12:684-701. https://doi.org/10.1016/j. phymed.2004.07.009 PMid:16194058

28. Lien H-C, Sun WM, Chen Y-H, et al. Effects of ginger on motion sickness and gastric slow-wave dysrhythmias induced by circular vection. Am J Physiol Gastrointest Liver Physiol. 2003; 284:G481-9. https://doi.org/10.1152/ ajpgi.00164.2002 PMid:12576305

29. Pertz HH, Lehmann J, Roth-Ehrang R, et al. Effects of ginger constituents on the gastrointestinal tract: role of cholinergic M3 and serotonergic 5-HT3 and 5-HT4 receptors. Planta Med. 2011; 77:973-8. https://doi. org/10.1055/s-0030-1270747 PMid:21305447

30. Tiran D. Ginger to reduce nausea and vomiting during pregnancy: Evidence of effectiveness is not the same as proof of safety. Complement Ther Clin Pract. 2012; 18:22-5. https://doi.org/10.1016/j.ctcp.2011.08.007 PMid:22196569
31. Pongrojpaw D, Somprasit C, Chanthasenanont A. A randomized comparison of ginger and dimenhydrinate in the treatment of nausea and vomiting in pregnancy. J Med Assoc Thail Chotmaihet Thangphaet. 2007; 90:1703-9.

32. Riyazi A, Hensel A, Bauer K, et al. The effect of the volatile oil from ginger rhizomes (Zingiber officinale), its fractions and isolated compounds on the 5-HT3 receptor complex and the serotoninergic system of the rat ileum. Planta Med. 2007; 73:355-62. https://doi.org/10.1055/s-2007-967171 PMid:17511060

33. Jiang X, Williams KM, Liauw WS, et al. Effect of ginkgo and ginger on the pharmacokinetics and pharmacodynamics of warfarin in healthy subjects. Br J Clin Pharmacol. 2005; 59:425-32. https://doi.org/10.1111/j.13652125.2005.02322.x PMid:15801937 PMCid:PMC1884814

34. Krüth P, Brosi E, Fux R, et al. Ginger-associated overanticoagulation by phenprocoumon. Ann Pharmacother. 2004; 38:257-60. https://doi.org/10.1345/ aph.1D225 PMid:14742762

35. Shalansky S, Lynd L, Richardson K, et al. Risk of warfarin-related bleeding events and supratherapeutic international normalized ratios associated with complementary and alternative medicine: A longitudinal analysis. Pharmacotherapy. 2007; 27:1237-47. https://doi. org/10.1592/phco.27.9.1237 PMid:17723077

36. Spolarich AE, Andrews L. An examination of the bleeding complications associated with herbal supplements, antiplatelet and anticoagulant medications. J Dent Hyg JDH Am Dent Hyg Assoc. 2007; 81:67.

37. Yamahara J, Miki K, Chisaka T, et al. Cholagogic effect of ginger and its active constituents. J Ethnopharmacol. 1985; 13:217-25. https://doi.org/10.1016/0378-8741(85)900091 